\title{
О славянской лексикографии в Эстонии
}

\author{
АЛИСИЯ ЧЕКАДА \\ Tartu Ülikooli Slaavi filoloogia osakond \\ Lossi 3, EE-51003 Tartu \\ E-mail: salasona@yandex.ru
}

(Received: 27 December 2015; accepted: 8 March 2016)

\begin{abstract}
Estonian-Slavic lexicography has a long tradition and is rich in achievements. In total, more than 120 Russian-Estonian and Estonian-Russian lexicographic manuals were released in the form of phrasebooks and printed or online dictionaries. Estonian-Polish lexicography is represented by several phrasebooks and pocket-size dictionaries. For the Estonian and Czech languages, there is only one dictionary and a phrasebook. Recently, a few projects have appeared for the production of the Estonian-Ukrainian, Estonian-Bulgarian, and BulgarianEstonian dictionaries but none of them have yet been completed. For other Slavic languages, no compilation of bilingual dictionaries is conducted.
\end{abstract}

Keywords: Estonian, Slavic, lexicography, bilingual dictionaries, phrasebooks

По словам Э. Росс, в Эстонии «традиция переводных словарей живет более трех с половиной столетий», но «о наличии действенной лексикографической системы эстонского языка можно говорить лишь в XX столетии» (РосС 1998: 45). В период Первой Эстонской республики (1918-1940) процесс составления и издания двуязычных словарей вышел на новый уровень. «Особенно хорошим подбором слов и необходимым числом удачных переводных соответствий отличались словари, подготовленные в 1930-е годы... В определенном отношении эти словари вполне удовлетворяют пользователей и сегодня〉 (Росс 1998: 46). Прежде всего, это англо-эстонский, финскоэстонский, шведско-эстонский, немецко-эстонский и русско-эстонский словари. Каждый из них переиздавался по несколько раз как в Эстонии, так и за ее пределами (Росс 1998: 47).

В сороковые годы XX в. работа лексикографов в Эстонии в силу исторических и идеологических причин была практически приостановлена. Лишь на рубеже 1950-1960-х гг. вновь стали появляться двуязычные словари. Среди славянских языков, представленных в качестве одной из параллелей в таких словарях, на первом месте, по-прежнему, оставался русский язык.

Если говорить в целом о плодах эстонско-русской лексикографии, то следует отметить, что на сегодняшний день имеется целый ряд исследований, посвященных различным аспектам изучения русского и эстонского языков. Выпущено большое количество русско-эстонских и эстонско-русских лексикографических пособий в виде словарей и разговорников. В Тартуском университете защищена докторская диссертация «Двуязычный словарь и функ- 
ционально значимые связи слова» О. Н. Паликовой, посвященная проблеме представления языкового материала в двуязычном словаре на материале русского и эстонского языков. Как отмечает О. Н. Паликова, «Русско-эстонская / эстонско-русская лексикография... существует около 120 лет и насчитывает около 120 изданий (не считая переизданий)» (ПАликовА 2007: 7).

Первые двуязычные словари для этой пары языков были изданы в Эстонии еще в конце XIX в. В роли первого эстонско-русского словаря выступает вышедший в 1890 г. словарь М. Залема «Эстско-русский словарь по Видеману» (SALEM 1890). Первый русско-эстонский словарь Wene-Eesti SõnaRaamat появился в 1885 г. (JOHANSON-P ÄRNA 1885); словарь выдержал 5 переизданий, последнее из которых вышло в 1917 г.

В числе общих и учебных словарей на данный момент имеется 14 эстонско-русских, 31 русско-эстонский и по одному двунаправленному словарю (эстонско-русско-эстонский, русско-эстонско-русский). Наиболее значимыми достижениями последнего времени являются большой эстонско-русский словарь в 5 томах (EVS 1997-2009), большой русско-эстонский словарь в 4 томах (РЭС 1984-1994) (переиздание 2000 г. вышло в 2 томах: VES 2000), однотомный русско-эстонский словарь (КӒнАR 2000). Для данной языковой пары вышел также ряд общих разговорников: 3 эстонско-русских, 9 русскоэстонских и 3 двунаправленных эстонско-русско-эстонских.

Кроме того существует большое количество узкоспециальных терминологических словарей и тематических разговорников. Изданы эстонско-русские словари сельскохозяйственной лексики, спортивных терминов, словарь по бухгалтерскому учету, технический, юридический, экономический и др. Всего подобных словарей имеется на сегодняшний день более 10. Число специализированных русско-эстонских изданий в два с половиной раза больше. Среди них - геологический, химический, горный, юридический, электротехнический, строительный, военный, медицинский и другие словари.

Больше всего (свыше 30) терминологических словарей и справочников для этой языковой пары составлено в формате двунаправленного эстонскорусско-эстонского издания. В этой группе широко представлены школьные словари понятий к курсам математики, истории, искусствоведения, химии, физики, биологии, географии и пр. дисциплин.

Помимо традиционных бумажных словарей существует и ряд онлайнсловарей. Институт эстонского языка на своем интернет-сайте (www.eki.ee) поместил эстонско-русский и русско-эстонский онлайн-словари, которые созданы на базе уже имеющихся печатных словарей: эстонско-русский словарь опирается на пятитомник (EVS 1997-2009), а русско-эстонский словарь основывается на двухтомнике (VES 2000). Существует еще несколько эстонскорусских и русско-эстонских онлайн-словарей, находящихся в открытом доступе (на сайтах www.dictionary.ee, www.annaabi.ee, www.vene-eesti.ase.ee).

Таким образом, мы можем говорить о том, «что русско-эстонская лексикография не только имеет долгую историю, но и богата достижениями» (ПАликовА 2007: 9). На этом фоне двуязычная польско-эстонская/эстонско- 
польская лексикография, как и сопоставительное изучение польского и эстонского языков, пока находится на начальном этапе развития.

Первым опытом составления учебного пособия для эстонского и польского языков стал двунаправленный эстонско-польско-эстонский разговорник Praktiline eesti-poola, poola-eesti käsiraamat/Praktyczny podręcznik estońsko-polski i polsko-estoński (NURMIK-SкOмOROWSKI 1937) (переиздания вышли в 1938 и 1939 гг.), содержавший небольшой сравнительно-сопоставительной грамматический очерк эстонского и польского языков. Этот разговорник в течение нескольких последующих десятилетий оставался первым и единственным в данной области. В 1980 г. вышел польско-эстонский разговорник Mini-rozmówki estońskie (SEPRE-SEPRE-WóJcıк 1980). В начале XXI в. вышли два общих эстонско-польских разговорника: в 2000 г. появился Eesti-poola vestmik/Rozmówki estońsko-polskie (MAJOR 2000) и в 2008 г. Eesti-poola vestmik (BOROWSKA-PETERSON-PETERSON 2008).

В течение последних 15 лет было выпущено три общих польско-эстонских словаря, кроме того, существует проект словаря «Польско-эстонскоанглийский электронный тематический словарь»/Polsko-estońsko-angielski elektroniczny stownik tematyczny (подробнее об этом проекте см. MATULEWSKAWASIELEWSKA 2004), но на данный момент работа над его созданием не закончена.

Польский язык оказался включенным в число девяти языков в словаре Languages around the Baltic Sea. Dictionary in Nine Languages. Keeled ümber Läänemere. Üheksakeelne sõnastik (KALJUSTE 1996).

В 2000 г. появился эстонско-польский словарь Eesti-poola sõnastik/Stownik estońsko-polski (ERIN-STEFAŃCZYK 2000a). В том же году Л. Эрин и В. Стефанчик издали в соавторстве первый учебник польского языка для эстонцев (ERIN-STEFAŃCZYK 2000b).

В 2010 г. вышел учебный двунаправленный эстонско-польско-эстонский словарь Język estoński dla początkujacych. Słownik estońsko-polski i polsko-estoński (BIELECKI 2010). Словарь издан в рамках проекта, включающего учебник эстонского языка для поляков, рабочую тетрадь и словарь (BIELECKI 2009, BIELECKI 2010, BIELECKI 2011). Все три книги рассчитаны на носителей польского языка, которые только начинают изучать эстонский язык.

Представленные данные позволяют говорить о том, что на эстонско-славянском фоне эстонско-польская лексикография представлена целым рядом справочников и словарей. Основная их часть появилась за последние 20 лет в период, когда тесные языковые и культурные контакты между Эстонией и Польшей обусловили необходимость составления учебников, справочников, разговорников и двуязычных словарей. Несмотря на то, что научная традиция в этой области еще не успела сформироваться, сделано за этот короткий период времени было довольно много. При этом на сегодняшний день эстонско-польская лексикография нуждается не только в новых изданиях, но, прежде всего, в теоретических работах по составлению словарей - как традиционных, так и словарей нового типа. 
В области создания лексикографических изданий по эстонскому и чешскому языкам имеется всего один словарь и разговорник. В 1966 г. появился первый чешско-эстонский словарь, составленный А. Райдом и С. Смирновым (RAID-SMIRNOV 1966), а в 1989 г. вышел чешско-эстонский разговорник (LEEMETS-SMIRNOv 1989). Некоторое время назад появились проекты по составлению эстонско-украинского, эстонско-болгарского и болгарско-эстонского словарей, но работа над ними пока не завершена. По другим славянским языкам составление двуязычных словарей пока не ведется.

\section{Словари}

BIELECKI 2009 = BIELECKI R. Język estoński dla początkujacych. Teksty i gramatyka. Poznań, 2009.

BIELECKI 2010 = BIELECKI R. Język estoński dla poczatkujących. Stownik estońsko-polski i polsko-estoński. Poznań, 2010.

BIELECKI 2011 = BIELECKI R. Język estoński dla poczatkujących. Ćwiczenia i rozwiazania . Poznań, 2011.

Borowska-Peterson-Peterson 2008 = Borowska-Peterson S., Peterson M. Eestipoola vestmik. Tallinn, 2008.

ERIN-StefańCZyk 2000a = Erin L., StefańCZyk W. Eesti-poola sõnastik. Stownik estońsko-polski. Kraków, 2000.

Erin-Stefańczyk 2000b = Erin L., Stefańczyk W. Poola keel. Podręcznik języka polskiego dla Estończyków. Warszawa, 2000.

EVS 1997-2009 = Eesti-vene sõnaraamat/Эстонско-русский словарь. Т. 1-5. Tallinn, $1997-2009$.

JohANSON-PÄrna 1885 = Wene-Eesti Sõna-Raamat. 16 tuhat Wenekeele sõna. Koolidele ja iseõppimiseks toimetanud J. Johanson-Pärna. Tallinn, 1885.

KäHAR $2000=$ KäHAR Andres: Vene-eesti sõnaraamat/Русско-эстонский словарь. Tallinn, 2000.

Kaljuste 1996 = Kaljuste T. Languages around the Baltic Sea. Dictionary in Nine Languages / Keeled ümber Läänemere. Üheksakeelne sõnastik. Tallinn, 1996.

LeEMETS-SMirnov 1989 = LeEMETS H., SMIRnov S. Tšehhi-eesti vestmik. Česko-estonská konverzace. Tallinn, 1989.

MAJOR 2000 = MAJOR M. Eesti-poola vestmik. Rozmówki estońsko-polskie. Tallinn, 2000.

NuRmiK-SKomorowski 1937 = NuRmiK M., SKOMOROwski E. Praktiline eesti-poola, poola-eesti käsiraamat. Praktyczny podręcznik estońsko-polski i polsko-estoński. Tartu, 1937.

RAID-Smirnov 1966 = RAID A., SmiRnov S. Třehhi-eesti sõnaraamat. Tallinn, 1966.

SAlem $1890=$ SAlem M. Eesti-Wene sõnaraamat Wiedemanni järele seadnud M. Salem. Tallinn, 1890.

Sepre-Sepre-Wójcik 1980 = Sepre W., Sepre R., WojciK A. Mini-rozmówki estońskie. Warszawa, 1980.

VES $2000=$ Vene-eesti sõnaraamat $/$ Русско-эстонский словарь. T. 1-2. Toimetanud Helle Leemets, Henn Saari ja Rein Kull. Tallinn, 2000.

РЭС 1984-1994 = Русско-эстонский словарь. Т. 1-4. Tallinn, 1984-1994. 


\section{Литература}

Matulewska-Wasielewska 2004 = Matulewska M., WasielewsKa M. Polsko-estońskoangielski elektroniczny słownik tematyczny. Investigationes Linguisticae 11. Poznań, 2004. 1-9.

ПАЛИКОВА $2007=$ ПАликОВА О. Двуязычный словарь и функционально значимые связи слова. (Dissertationes Philologiae Slavicae Universitatis Tartuensis 18.) Tartu, 2007.

Росс 1998 = Росс Э. Эстонская лексикография во второй половине ХХ столетия. Направления развития и выводы. Linguistica Uralica 34 (1998): 45-52. 